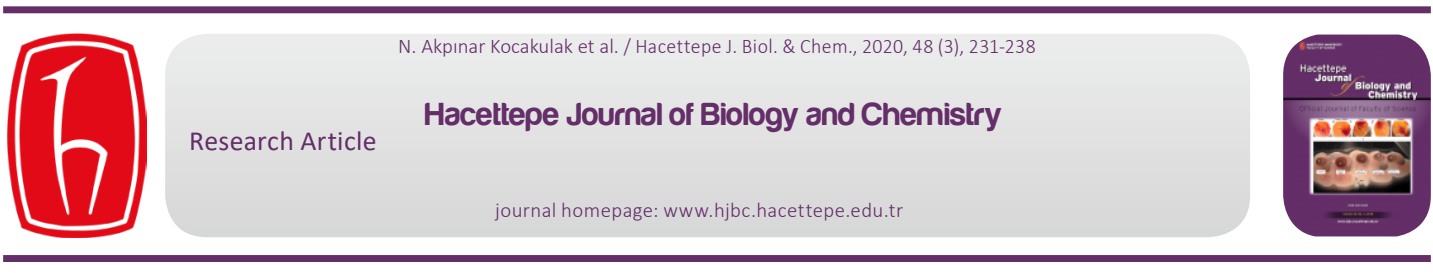

\title{
The Effect of Exercise at High Altitude on Muscle Serum Enzymes and Some Biochemical Parameters
}

\section{Yüksek İrtifada Yapılan Egzersizin Kas Serum Enzimleri ve Bazı Biyokimyasal Parametrelere Etkisi}

\author{
Neşe Akpınar Kocakulak ${ }^{1^{*} \oplus}$, Meryem Şentürk ${ }^{2 \oplus}$, Hakan Gülmez $^{3 \oplus}$, Meryem Eren ${ }^{2}{ }^{\circ}$, Zuhal Hamurcu ${ }^{4}$ \\ ${ }^{1}$ Faculty of Health Sciences, Department of Sport Science, İzmir Democracy University, İzmir, Türkiye. \\ ${ }^{2}$ Faculty of Veterinary Medicine, Department of Basic Sciences, Erciyes University, Kayseri, Türkiye. \\ ${ }^{3}$ Faculty of Medicine, Department of Family Medicine, Izmir Democracy University, İzmir, Türkiye. \\ ${ }^{4}$ Medical Faculty, Department of Medical Biology, Betül Ziya Eren Genome and Stem Cell Center, Erciyes University, Kayseri, Türkiye.
}

\section{ABSTRACT}

$\mathrm{H}$ igh altitude conditions cause changes in organism functions. Low oxygen concentration, low heat and exposure to ultraviolet rays for a long time trigger these changes. In our study, the effects of exercise at $1055 \mathrm{~m}$ and $2500 \mathrm{~m}$ on: the levels or activities of malondialdehyde (MDA), creatinine, lactate dehydrogenase (LDH) and aspartate aminotransferase (AST), total protein, glucose, cholesterol were investigated. Twelve healthy individuals were included in the study. They exercised 3 hours a day for 5 days in both altitudes. Blood samples were taken and placed into the tubes with anticoagulants, both at the first day and on the fifth day, at $1055 \mathrm{~m}$ and $2500 \mathrm{~m}$ altitude before and after exercise, the samples were then centrifuged and separated from their plasma. The resuts indicate that glucose and AST (aspartate aminotransferase) increased at 2500 meters, while MDA (malondialdehyde) decreased. At 1500 meters, glucose and creatinine were found to be released, while AST (aspartate aminotransferase) was decreased. Considering the samples taken 10 days after the volunteers returned from $2500 \mathrm{~m}$ to $1055 \mathrm{~m}$, the results were found to approach $2500 \mathrm{~m}$ pre-exercise values. When the results of $1055 \mathrm{~m}$ and $2500 \mathrm{~m}$ were compared to the $1^{\text {st }}$ and $5^{\text {th }}$ days, glucose and creatinine were found to be increased both at $1050 \mathrm{~m}$ and at $2500 \mathrm{~m}$. It was observed that LDH (lactate dehydrogenase) increased significantly at $5^{\text {th }}$ of $2500 \mathrm{~m}$ compared to $1^{\text {st }}$ day. Our results showed that both exercise and high altitude affect muscle serum enzymes and glucose MDA values, but these changes do not pose a risk of disease that would require medical intervention.

\section{Key Words}

Exercise, high altitude, hypoxia, biochemical parameter, muscle serum enzymes.

\section{öz}

\begin{abstract}
Y üksek irtifa şartları organizma fonksiyonlarında değişimlere neden olur. Solunan havadaki düşük oksijen konsantrasyonu, düşük ısı ve uzun sure ultraviyole ışınlarına maruz kalmak bu değişiklileri tetiklemektedir. Çalışmamız $1055 \mathrm{~m}$ ve 2500 m'de yapılan egzersizin Malondialdehit (MDA), Kreatinin, LaktatDehidrojenaz (LDH) ve AspartatAminotransferaz (AST), Total Protein, Glucose, Kolestorol üzerine etkisi belirlenmeye çalışımıştır. Çalışmaya 12 sağlıklı birey dahil edildi. Her iki yerde 5 gün boyunca günde 3 saat egzersiz yaptılar. Egzersizden önce ve egzersizden hemen sonra $1055 \mathrm{~m}$ ve $2500 \mathrm{~m}$ yükseklikte hem ilk gün hem de beşinci günde Antikoagülantlı tüplere alınan kan örnekleri santrifüj edilerek plazmalarına ayrılmıştır. 2500 metrede Glucose ve AST (aspartat aminotransferaz) artış gösterdiği bulundu. MDA (malondialdehid) ise azalmıştır. 1500 metrede ise yine Glucose, kreatinin arttığı bulunurken, AST (aspartataminotransferaz) azalmıştır. Gönüllüler 2500 m'den 1055 m'ye geri döndükten 10 gün sonra alınan örnekler değerlendirildiğinde sonuçların 2500 m egzersiz öncesi değerlerine yaklaştığı bulunmuştur. 1055 m ve 2500 m 1. ve 5. gün sonuçları karşılaştırıldığında Glucose ve kreatinin hem $1050 \mathrm{~m}$ de hem de $2500 \mathrm{~m}$ de arttığı bulunmuştur. LDH (laktatdehidrogenaz)'ın $2500 \mathrm{~m}$ de 1. Güne göre 5. gün büyük oranda artış gösterdiği görülmektedir. Sonuçlarımız hem egzersizin hem de yüksek irtifanın kas serum enzimleri, Glucose ve MDA değerlerini değiştirdiği fakat bu değişikliklerin tıbbi bir müdahale gerektirecek hastalık riski oluşturmadığını göstermiştir.
\end{abstract}

\section{Anahtar Kelimeler}

Egzersiz, yüksek irtifa, hipoksi, biyokimyasal parametre, kas serum enzimleri. 


\section{INTRODUCTION}

ody regulation mechanisms for survival in hypobaric hypoxic environments differ in each height environment. Height training is used by coaches and athletes both to acclimate for high-altitude competitions and to prepare for competitions at sea level [1]. There are researchers who argue that high-altitude training will increase aerobic performance, as well as authors who argue that it is no use to high-performance athletes. Exposure to low oxygen pressure is known to cause both metabolic and physiological changes [2,3]. Although oxygen demand will be limited due to hypoxia at high altitude, it is reported that exposure to high altitude (due to changes in ROS formation and antioxidant activity) can also cause oxidative damage, although production of reactive oxygen derivatives (ROS will be low [4]. ROSs contain one or more unpaired electrons with high energy. Normal cell metabolism converts $1-2 \%$ of oxygen molecules into ROSs. This ROS is potentially toxic. Although ROS has important contributions in regulating normal physical activities such as muscle contraction, significant increases in concentrations of ROSs can disrupt normal cell function, leading to oxidative damage of various biomolecules (protein, lipid) and cellular DNA [5,6]. Because of its role in organ, tissue damage and the etiopathogenesis of different diseases, ROS has been an increasingly popular field of medicine in recent years. High altitude conditions cause changes in organism functions. Low oxygen concentration, low heat and exposure to ultraviolet rays for a long time trigger these changes. Deep respiratory movements, increased heart rate, increased number of circulating erythrocytes and increased hemoglobin concentrations are the effects of acclimation to high altitude conditions. Because of these effects, camping in a hypoxic environment is used as a training program for professional athletes [7,8]. Malondialdehyde (MDA) levels have been measured in many studies as an indicator of oxidative stress [9]. Malondialdehyde (MDA) is one of the toxic end products produced by the breakdown of non-enzymatic oxidative lipid peroxides. Malondialdehyde (MDA) levels have been measured in many studies as an indicator of oxidative stress [9]. In clinical situations, Creatinine, Lactate Dehydrogenase (LDH) and Aspartate Aminotransferase (AST) are widely used in the diagnosis of skeletal muscle damage and tissue damage in skeletal muscles. At the same time, it is not yet fully understood how long-term excursion to high altitude affects glucose homeostasis. In addition, mild neuroglycopenia at high altitude can have serious side effects. Studies have emphasized that the effects of exogenous carbohydrate oxidation during exercise are not clear but can reflect differences in exercise intensity. In related studies, the effect of hypoxia on lipid peroxidation has been studied and studies on different examples of oxidative damage (such as blood, skeletal muscle, liver) have been limited and contradictory results have been obtained. [2]. In our study, we tried to determine the effect of height hypoxia in different climatic conditions when the exercise was performed under these conditions by examining the levels of Malondialdehyde (MDA), Creatinine, Lactate Dehydrogenase (LDH) and Aspartate Aminotransferase (AST), Total Protein, Glucose, Cholesterol.

\section{MATERIALS and METHODS}

Subjects: The study group consisted of 12 people with similar age and physical characteristics. The average age was $17.25 \pm 1.14$ years, the average height was $165.92 \pm 2.61 \mathrm{~cm}$. The average body mass and body mass index were $60.58 \pm 2.84 \mathrm{~kg}$ and $21.28 \pm 0.75 \mathrm{~kg} /$ $\mathrm{m}^{2}$ (mean $\left.\pm S D\right)$, respectively. The people included in the study lived at an altitude of $1055 \mathrm{~m}$ above sea level and were not interested in skiing before. All subjects did not experience high altitude conditions for at least 6 months. Informed consent was obtained from all subjects before the study. The study protocol and the procedures were approved by the local ethical committee (No 09/54). The study was conducted in accordance with the Declaration of Helsinki or local laws depending on whichever afforded greater protection for the subjects.

Experimental protocols: Test protocols were performed on two locations: the studies at 1055 meters were performed at the Erciyes University campus which is located on the skirts of Erciyes Mountain (3917 m above sea level), Turkey/Kayseri. $2500 \mathrm{~m}$ high altitude studies were performed at the Erciyes ski-centre on the Erciyes Mountain

$\mathbf{2 5 0 0}$ meters studies; The subjects arrived after an hour by bus due to the fact that the centre is $25 \mathrm{~km}$ away from the town center of Erciyes Mountain. Experiments were started after two hours. They did basic interval ski exercises at $2500 \mathrm{~m}$. Their heart rhythm was kept between 140-160 beats/minute and they exercised on skis for 3 hours per day for 5 days. All subjects stayed at $2200 \mathrm{~m}$ altitude at Erciyes Mountain during the 5 days. Experiments were conductedon January 2 through6. 
1055 meters studies; the subjects came back down to $1055 \mathrm{~m}$ from the mountain after two weeks (January 25-29) and began to work again. All the subjects performed the same exercises at $1055 \mathrm{~m}$ as they did at $2500 \mathrm{~m}$. They performed exercise for 3 hours per day for 5 days. Their heart rhythms were kept between 140-160 beats/ minute during exercise.

1st day and 5th day oxygen saturation, systolic and diastolic blood pressures, heart rate and Malondialdehyde (MDA), Creatine, Lactate Dehydrogenase (LDH) and Aspartate Aminotransferase (AST), Total Protein, Glucose, Colesterol levels or activities were measured before exercise and immediately after exercise at the two locations.
Collection of Samples: Five milliliters of heparinised peripheral blood samples were obtained before exercise and immediately after the exercise at $1055 \mathrm{~m}$ and $2500 \mathrm{~m}$ altitudes on both first day and fifth day. Also, the subjects came back down to $1055 \mathrm{~m}$ from the mountain, and the blood samples were taken after resting for ten days (January 17).

Performing Biochemical Analysis: Blood samples taken into anticoagulated tubes were centrifuged and separated into their plasma. Blood samples taken into anti-coagulant tubes were kept at room temperature for one hour, and then their serum was separated by centrifugation at 3000

Table 1. Comparison of biochemical parameters at $2500 \mathrm{~m}$.

\begin{tabular}{|c|c|c|c|c|}
\hline $\begin{array}{c}p \text { value } \\
\text { (Between Before-After) }\end{array}$ & Mean $\pm S D$ & $\begin{array}{c}\text { Tests } \\
\text { (Mountain 2500m) }\end{array}$ & $\begin{array}{l}\text { Mean } \pm \text { SD } \\
\text { (10th day) }\end{array}$ & $\begin{array}{c}\mathrm{p} \text { value } \\
\text { (Between 10th day) }\end{array}$ \\
\hline \multirow{2}{*}{$0.01^{*}$} & $-0.21 \pm 2.04$ & AST Day 1 Before & $0.36 \pm 0.19$ & 0.35 \\
\hline & $2.28 \pm 1.80$ & AST Day 1 After & $0.36 \pm 0.19$ & $0.003^{*}$ \\
\hline \multirow{2}{*}{0.72} & $1.46 \pm 0.86$ & AST Day 5 Before & $0.36 \pm 0.19$ & $0.002^{*}$ \\
\hline & $1.32 \pm 1.12$ & AST Day 5 After & $0.36 \pm 0.19$ & $0.02 *$ \\
\hline \multirow{2}{*}{$0.09 *$} & $6.16 \pm 0.23$ & Total Protein Day 1 Before & $6.02 \pm 0.13$ & 0.15 \\
\hline & $6.04 \pm 0.05$ & Total Protein Day 1 After & $6.02 \pm 0.13$ & 0.66 \\
\hline \multirow{2}{*}{0.66} & $6.19 \pm 0.15$ & Total Protein Day5 Before & $6.02 \pm 0.13$ & $0.009 *$ \\
\hline & $6.16 \pm 0.13$ & Total Protein Day 5 After & $6.02 \pm 0.13$ & 0.07 \\
\hline \multirow{2}{*}{$0.001^{*}$} & $65.92 \pm 7.88$ & Glucose Day 1 Before & $79.46 \pm 13.76$ & $0.001^{*}$ \\
\hline & $75.98 \pm 2.07$ & Glucose Day 1 After & $79.46 \pm 13.76$ & 0.40 \\
\hline \multirow{2}{*}{0.22} & $71.40 \pm 22.09$ & Glucose Day 5 Before & $79.46 \pm 13.76$ & 0.33 \\
\hline & $79.74 \pm 1.82$ & Glucose Day 5 After & $79.46 \pm 13.76$ & 0.94 \\
\hline \multirow{2}{*}{0.28} & $181.83 \pm 14.60$ & Cholesterol Day 1Before & $190.59 \pm 9.99$ & 0.11 \\
\hline & $188.15 \pm 19.05$ & Cholesterol Day 1 After & $190.59 \pm 9.99$ & 0.39 \\
\hline \multirow{2}{*}{0.44} & $193.63 \pm 14.63$ & Cholesterol Day 5 Before & $190.59 \pm 9.99$ & 0.78 \\
\hline & $187.08 \pm 23.11$ & Cholesterol Day 5 After & $190.59 \pm 9.99$ & 0.86 \\
\hline \multirow{2}{*}{$0.001^{*}$} & $3.37 \pm 0.76$ & MDA Day 1 Before & $3.90 \pm 0.71$ & 0.20 \\
\hline & $1.63 \pm 0.36$ & MDA Day 1 After & $3.90 \pm 0.71$ & $0.000^{* *}$ \\
\hline \multirow{2}{*}{0.63} & $3.19 \pm 1.41$ & MDA Day 5 Before & $3.90 \pm 0.71$ & 0.08 \\
\hline & $3.45 \pm 1.02$ & MDA Day 5 After & $3.90 \pm 0.71$ & 0.19 \\
\hline \multirow{2}{*}{0.19} & $125.44 \pm 64.94$ & Creatinine Day 1 Before & $98.77 \pm 31.25$ & 0.20 \\
\hline & $262.88 \pm 274.17$ & Creatinine Day 1 After & $98.77 \pm 31.25$ & 0.10 \\
\hline \multirow{2}{*}{0.86} & $699.90 \pm 587.71$ & Creatinine Day 5 Before & $98.77 \pm 31.25$ & $0.01^{*}$ \\
\hline & $744.70 \pm 715.70$ & Creatinine Day 5 After & $98.77 \pm 31.25$ & $0.02^{*}$ \\
\hline \multirow{2}{*}{0.74} & $361.12 \pm 74.64$ & LDH Day 1 Before & $589.66 \pm 146.31$ & 0.68 \\
\hline & $351.87 \pm 78.88$ & LDH Day 1 After & $589.66 \pm 146.31$ & $0.02^{*}$ \\
\hline \multirow{2}{*}{0.11} & $717.00 \pm 184.02$ & LDH Day 5 Before & $589.66 \pm 146.31$ & 0.36 \\
\hline & $822.10 \pm 162.28$ & LDH Day 5 After & $589.66 \pm 146.31$ & 0.83 \\
\hline
\end{tabular}


rpm for 10 minutes. Serum and plasma samples were kept at $-20{ }^{\circ} \mathrm{C}$ until analysis was performed. Serum biochemical parameter levels (AST, LDH, glucose, cholesterol, total protein, creatinine)were analyzed with commercial kits (Biolabo, France) and plasma MDA levels, Moreno et al. [10] were determined according to the method utilizing the spectrophotometer (UV/VIS Shimadzu 1208, Japan).

Statistical analysis: The Statistical package for social sciences (SPSS) for Windows ver. 16.0 (SPSS Inc., Chicago, IL) was used for statistical analyzes. The paired samples t-tests were employed to do the comparison of measurable variables. A significant level was set at a $P$ - value of $<0.05$.

\section{Results}

The study was conducted with 12 people with similar age and physical properties and average age was $17.25 \pm 1.14$ years, average height length was $165.92 \pm 2.61 \mathrm{~cm}$, average body mass was $60.58 \pm 2.84 \mathrm{~kg}$ and body mass index $21.28 \pm 0.75 \mathrm{~kg} / \mathrm{m}^{2}$ (mean $\left.\pm S D\right)$.

At $2500 \mathrm{~m}$ (height of hypoxia), AST, total protein, and glucose increased on the first day before and immediately after the exercise, while a decrease in MDA was detected ( $p<0.05 ; p<0.001)$. It was found that the changed values returned to the reference ranges of the

Table 2. Comparison of biochemical parameters at $1055 \mathrm{~m}$

\begin{tabular}{|c|c|c|c|c|}
\hline $\begin{array}{c}\text { p value } \\
\text { (Between Before-After) }\end{array}$ & Mean $\pm S D$ & $\begin{array}{l}\text { Tests } \\
(1055 \mathrm{~m})\end{array}$ & $\begin{array}{l}\text { Mean } \pm S D \\
\text { (10th day) }\end{array}$ & $\begin{array}{c}\text { p value } \\
\text { (Between 10th day) }\end{array}$ \\
\hline \multirow{2}{*}{$0.04^{*}$} & $0.59 \pm 0.43$ & AST Day 1 Before & $0.36 \pm 0.19$ & 0.07 \\
\hline & $0.32 \pm 0.15$ & AST Day 1 After & $0.36 \pm 0.19$ & 0.57 \\
\hline \multirow{2}{*}{0.92} & $0.33 \pm 0.20$ & AST Day 5 Before & $0.36 \pm 0.19$ & 0.78 \\
\hline & $0.34 \pm 0.25$ & AST Day 5 After & $0.36 \pm 0.19$ & 0.81 \\
\hline \multirow{2}{*}{0.37} & $6.12 \pm 0.15$ & Total Protein Day 1 Before & $6.02 \pm 0.13$ & 0.08 \\
\hline & $6.05 \pm 0.15$ & Total Protein Day 1 After & $6.02 \pm 0.13$ & 0.64 \\
\hline \multirow{2}{*}{0.18} & $5.97 \pm 0.17$ & Total Protein Day 5 Before & $6.02 \pm 0.13$ & 0.43 \\
\hline & $6.04 \pm 0.14$ & Total Protein Day 5 After & $6.02 \pm 0.13$ & 0.74 \\
\hline \multirow{2}{*}{$0.000 * *$} & $87.02 \pm 10.87$ & Glucose Day 1 Before & $79.46 \pm 13.76$ & 0.12 \\
\hline & $130.22 \pm 18.48$ & Glucose Day 1 After & $79.46 \pm 13.76$ & $0.000 * *$ \\
\hline \multirow{2}{*}{0.94} & $123.33 \pm 19.96$ & Glucose Day 5 Before & $79.46 \pm 13.76$ & $0.000 * *$ \\
\hline & $123.60 \pm 25.17$ & Glucose Day 5 After & $79.46 \pm 13.76$ & $0.000 * *$ \\
\hline \multirow{2}{*}{0.51} & $186.63 \pm 11.61$ & Cholesterol Day 1 Before & $190.59 \pm 9.99$ & 0.69 \\
\hline & $191.05 \pm 13.88$ & Cholesterol Day 1 After & $190.59 \pm 9.99$ & 0.44 \\
\hline \multirow{2}{*}{0.05} & $190.81 \pm 15.26$ & Cholesterol Day 5 Before & $190.59 \pm 9.99$ & 0.37 \\
\hline & $179.66 \pm 17.44$ & Cholesterol Day 5 After & $190.59 \pm 9.99$ & 0.24 \\
\hline \multirow{2}{*}{0.31} & $4.12 \pm 1.32$ & MDA Day 1 Before & $3.90 \pm 0.71$ & 0.93 \\
\hline & $3.50 \pm 0.67$ & MDA Day 1 After & $3.90 \pm 0.71$ & 0.15 \\
\hline \multirow{2}{*}{0.56} & $3.70 \pm 0.61$ & MDA Day 5 Before & $3.90 \pm 0.71$ & 0.14 \\
\hline & $3.54 \pm 0.33$ & MDA Day 5 After & $3.90 \pm 0.71$ & 0.12 \\
\hline \multirow{2}{*}{0.01} & $56.77 \pm 17.14$ & Creatinine Day 1 Before & $98.77 \pm 31.25$ & $0.003^{*}$ \\
\hline & $77.00 \pm 22.24$ & Creatinine Day 1 After & $98.77 \pm 31.25$ & $0.02 *$ \\
\hline \multirow{2}{*}{0.88} & $100.44 \pm 49.12$ & Creatinine Day 5 Before & $98.77 \pm 31.25$ & 0.76 \\
\hline & $104.88 \pm 56.01$ & Creatinine Day 5 After & $98.77 \pm 31.25$ & 0.52 \\
\hline \multirow{2}{*}{0.10} & $359.66 \pm 87.21$ & LDH Day 1 Before & $589.66 \pm 146.31$ & 0.42 \\
\hline & $444.66 \pm 149.01$ & LDH Day 1 After & $589.66 \pm 146.31$ & 0.28 \\
\hline \multirow{2}{*}{0.27} & $398.44 \pm 78.89$ & LDH Day 5 Before & $589.66 \pm 146.31$ & 0.90 \\
\hline & $443.00 \pm 91.06$ & LDH Day 5 After & $589.66 \pm 146.31$ & 0.17 \\
\hline
\end{tabular}

${ }^{*} p<0.05 ;{ }^{* *} p<0.001$ 
Table 3. Comparison of $2500 \mathrm{~m}$ and $1055 \mathrm{~m} 1 \mathrm{st}$ day and 5 th day results.

\begin{tabular}{|c|c|c|}
\hline Parameters & Mean & $p$ value \\
\hline AST_2500m_1_EO & $-0.21 \pm 2.04$ & \multirow{2}{*}{0.07} \\
\hline AST_2500m_5_ES & $1.32 \pm 1.12$ & \\
\hline AST_1055m_1_EO & $0.59 \pm 0.43$ & \multirow{2}{*}{0.06} \\
\hline AST_1055m_5_ES & $0.34 \pm 0.25$ & \\
\hline Total Protein_2500m_1_EO & $6.16 \pm 0.23$ & \multirow{2}{*}{0.97} \\
\hline Total Protein 2500m_5_ES & $6.16 \pm 0.13$ & \\
\hline Total Protein_1055m_1_O & $6.12 \pm 0.15$ & \multirow{2}{*}{0.33} \\
\hline Total Protein_1055m_5_S & $6.04 \pm 0.14$ & \\
\hline Glucose2500m_1_0 & $65.92 \pm 7.88$ & \multirow{2}{*}{$0.000 * *$} \\
\hline Glucose2500m_5_S & $79.74 \pm 1.82$ & \\
\hline Glucose1055m_1_O & $87.02 \pm 10.87$ & \multirow{2}{*}{$0.001^{*}$} \\
\hline Glucose_1055m_5_S & $123.60 \pm 25.17$ & \\
\hline Cholesterol_2500m_1_0 & $181.83 \pm 14.60$ & \multirow{2}{*}{0.56} \\
\hline Cholesterol_2500m_5_S & $187.08 \pm 23.11$ & \\
\hline Cholesterol 1055m_1_O & $186.63 \pm 11.61$ & \multirow{2}{*}{0.30} \\
\hline Cholesterol_1055m_5_S & $179.66 \pm 17.44$ & \\
\hline MDA_2500m_1_O & $3.37 \pm 0.76$ & \multirow{2}{*}{0.97} \\
\hline MDA_2500m_5_S & $3.45 \pm 1.02$ & \\
\hline MDA_1055m_1_O & $4.12 \pm 1.32$ & \multirow{2}{*}{0.44} \\
\hline MDA_1055m_5_S & $3.54 \pm 0.33$ & \\
\hline Creatinine_2500m_1_0 & $125.44 \pm 64.94$ & \multirow{2}{*}{$0.03 *$} \\
\hline Creatinine_2500m_5_S & $744.70 \pm 715.70$ & \\
\hline Creatinine1055m_1_0 & $56.77 \pm 17.14$ & \multirow{2}{*}{0.05} \\
\hline Creatinine1055m_5_S & $104.88 \pm 56.01$ & \\
\hline LDH_2500m_1_O & $361.12 \pm 74.64$ & \multirow{2}{*}{$0.000 * *$} \\
\hline LDH_2500m_5_S & $822.10 \pm 162.28$ & \\
\hline LDH_1055m_1_O & $359.66 \pm 87.21$ & \multirow{2}{*}{0.43} \\
\hline LDH_1055m_5_S & $443.00 \pm 91.06$ & \\
\hline
\end{tabular}

${ }^{*} \mathrm{p}<0.05^{* *} \mathrm{p}<0.001$

biochemical parameters after resting for 10 days following the time that the subjects returned to $1055 \mathrm{~m}$ ( $\mathrm{p}$ $<0.05$; $p<0.001$ ).

At 1055 m, increase in glucose, creatinine levels and decrease AST levels were observed immediately after the exercise on the first day ( $p<0.05 ; p<0.001)$. It was found that the biochemical parameters returned to the reference ranges as at $2500 \mathrm{~m}$ on the 10th day $(p<0.05$; $\mathrm{p}<0.001)$.

\section{Discussion}

For years, it has been thought that training should be done at high altitude to improve the performance of individuals at sea level. High altitude conditions cause changes in organism functions. Low oxygen concentration in the inhaled air, low heat, wind and exposure to ultraviolet rays for a long time trigger these changes $[2,11]$. Recent research suggests that high altitude-related hypoxia may be a model for long-term oxidative stress in healthy people. This study examined the effects of exposure to two independent inducers (exer- 
cise and altitude) on the levels or activities of muscle serum enzymes (creatine, AST, LDH) and Glucose, Total protein, Cholesterol and MDA. In this study, we found that AST, Glucose, Creatine, LDH values increased after exercise at both $2500 \mathrm{~m}$ and $1055 \mathrm{~m}$. In addition, AST, Creatine, LDH values were found to be higher than $2500 \mathrm{~m}$ altitude, except for glucose which was affected at an altitude of $2500 \mathrm{~m}$. This shows that both exercise and height change the levels of muscle enzymes. The effects of exercise on muscle damage at high altitude are unknown. Studies emphasize that muscle enzyme levels should be interpreted cautiously. In particular, serum CK levels rise immediately after loading, and this height lasts for several days. The high serum CK level is attributed to increased muscular membrane permeability due to low oxygen delivery during contraction [12]. More recent research reports that this enzyme due to muscle fiber damage appears, reaches peak levels in the blood within 3-5 days, and this peak reflects the release of CK from the damaged muscle and its excretion in the reticuloendothelial system. In addition, serum CK levels are linked to many factors such as gender, age, ethnicity, basic muscle composition, and physical activity levels. Magrini at al. [13] conducted a study with 669 ultramaraton $(161 \mathrm{~km})$ runners gathered at high altitude (2800 - 3840 m). 352 people of the runners who participated in the ultra marathon completed the race. Of these, only 36 people gave blood samples before and after, and the mean serum CK levels increased in these samples. It is also stated that this increase may be caused by high altitude environmental factors such as downhill and uphill strenuous eccentric contractions and low oxygen concentration, extreme low and high temperature, ultraviolet radiation and extreme wind changes. It is stated that in any damage to the skeletal muscles, as in the heart and liver, the AST value in the blood increases as in Creatine and LDH. Studies emphasize that LDH values increase especially in hypoxia. In our study, it is seen that it especially increased at $2500 \mathrm{~m}$. Physical exercise causes an increase in blood sugar levels, especially in high-intensity activity, mobilized from muscles and liver glycogenes to meet energy demands. Glucose for muscle activity is the fuel of choice by many cells [14]. Glucose is the most efficient fuel the body can use, consuming less oxygen than fat or protein per unit of energy produced [15]. Studies on humans and rodents show that acute exercise increases the transport of insulin-stimulated glucose to the muscles to meet physiologically relevant requirements [16]. Sufficient insulin is required for glucose and amino acids to enter the cells, thus providing fuel and essential elements for muscle activity. It is emphasized that plasma insulin increases during intense exercise to regulate glucose level and restore muscle glycogen [17]. There are contradictory results regarding the fasting glycemia increased, decreased and remained unchanged for healthy individuals exposed to high altitude. It is stated that these differences may be related to the high altitude exposure time [18]. It is stated that there is an increase in fasting glycemia in the first two days at high altitude. However, as the length of stay prolongs, acclimatization is provided and the resulting hyperglycemia is normalized and it is stated that it may fall below the pre-exposure values [19]. In our study, glucose levels increased at both heights. It is seen that this increase is more than 1055 meters. These results are important in that both high altitude and exercise cause an increase in muscle serum enzymes (AST, LDH, Creatine) and glucose. Studies in humans have reported conflicting results regarding the relationship between short-term (1-4 weeks) height hypoxia and oxidative stress. Some studies have found an increase in markers showing oxidative damage, such as lipid peroxidation [20], other studies have suggested that hypoxia is not associated with increased lipid peroxidation [21]. Several studies have reported that increased lipid peroxidation is associated with exercise [22,23]. Gonzalez at al. [24] studied 7 volunteers aged 19 to 23 years, who stayed for 3 days at an altitude of $3500 \mathrm{~m}$ above the sea level, and when they returned after 3 days, they investigated the effects of normal hypoxic conditions on these individuals. They took blood samples from the individuals in restful conditions and in both conditions they measured MDA, which is an indicator of oxidative damage in erythrocyte membrane lipids. When people returned to sea level again, they found that the MDA content increased significantly compared to the MDA content at altitude. Based on these results, they suggested that when people returning to work or having fun at $3500 \mathrm{~m}$ altitude back to sea level (reoxygenation), the risk of oxidative damage may occur in erythrocyte membrane lipids. At high altitude $(2500 \mathrm{~m})$, there is a decrease in MDA value after exercise compared to Day 1 before exercise. In normoxia, it is estimated that approximately 2-3\% of oxygen in the mitochondrial electron transport chain is reduced to water to form reactive oxygen derivatives (ROS) instead of ATP production [25]. In hypoxia, a decrease in the production of mitochondrial ROS has been reported due to the decrease in the amount of oxygen and the cessation of mitochondrial respiration 
[26]. Maintaining homeostasis against adverse effects caused by stress depends on autonomic, hormonal, metabolic and immunological responses of the organism. As partial air expands, oxygen pressure decreases at altitude and affects the delivery of oxygen to working tissues, regardless of whether a person is moving uphill or downhill. It is reported that the altitudes can be divided into low altitude $(<2,500 \mathrm{~m})$, high altitude $(2,500$ $m-3,500 \mathrm{~m})$, very high altitude $(3,500 \mathrm{~m}-5,800 \mathrm{~m})$ and extreme altitude (>5,800 m) [27]. In our study, we limited altitude to two altitude classes (1055 $\mathrm{m}$ and 2500 m). Volunteers returned from $2500 \mathrm{~m}$ to $1055 \mathrm{~m}$ after 5 days. Biochemical parameters were re-evaluated at the 10th day after the volunteers returned from 2500 $\mathrm{m}$ to $1055 \mathrm{~m}$. We can say that at the end of 10 days, muscle serum enzymes, glucose and MDA returned to pre-exercise values or started to return. We think that it is important to consider the 10 day duration, which is sufficient forthe negative effects of high altitude to diminish. This information could be useful to determine the time periods to be restarted after descending from the elevation before programming the high-altitude training. As a result, both exercise and high altitude show that muscle serum enzymes, glucose and MDA values change but these changes do not pose any disease risk and do not require medical intervention.

\section{References}

1. Z. Ying, C. Ning, Autophagy Is a Promoter for aerobic exercise performance during high altitude training, Oxid. Med. Cell. Longev., 2018 (2018) 3617508-3617511.

2. P. Moller, L. Stefen, C. Lundby, N.V. Olsen Acute hypoxia and hypoxic exercise induce DNA strand breaks and oxidative DNA damage in humans, FASEB., 15 (2005) 1181-1186.

3. N.A. Kocakulak, The effect of high altitude exercise on oxidative stress Level, Nat. Appl. Sci. J., 1 (2018) 1-8.

4. J.A. Jefferson, J. Simoni, E. Escudero, M.E. Hurtado, E.R.Swenson, D.E.Wesson, G.F.Schreiner, R.B. Schoene, R.J. Johnson, A. Hurtado, Increased oxidative stress following acute and chronic high altitude exposure, High Altitude Med. Biol., 5 (2004) 61-69.

5. Z. Radak, J. Pucsuk, S. Boros, L. Josfai, AW. Taylor, Changes in urine 8 htdroxydeoxyguanozine levels of super marathon runners during a four-day race period, Life Sci., 66 (2000) 1763-1767.

6. H. Orhan, B. Van Holland, B. Krab, J. Moeken, N.P. Vermeulen, P. Hollander, J.H. Meerman, Evaluation of a multiparameter biomarker set for oxidative damage in man: Increased urinary excretion of lipid, protein and DNA oxidation products after one hour of exercise, Free Radic. Res., 38 (2004) 1269-1279.

7. R.J. Bloomer, A. H.Goldfarb, J.M. Mckenzie, Oxidative stress response to aerobic exercise: Comparison of antioxidant supplements, Med. Sci. Sports Exerc., 38 (2006) 1098-105.
8. A. Harman, S. Pfuhler, C. Dennog, D. Germadnik, A. PIlger, G. Speit, Exercise-induced DNA effects in human leukocytes are not accompanied by increased formation of 8-Hydroxy2'-Deoxyguanosine or induction of micronuclei, Free Radic. Biol. Med., 24 (1997) 245-251.

9. M.L. Urso, P.M. Clarkson, Oxidative stress, exercise, and antioxidant supplementation, Toxicology, 189 (2003) 41-54.

10. I.M. Moreno, A. Mate, G. Repetto, C.M. Vázquez, A.M. Cameán, Influence of microcystin LR on the activity of membrane enzymes in rat intestinal mucosa, J. Physiol. Biochem., 59 (2003) 293-300.

11. Dosek, H.Ohno, Z. Acs, A.W. Taylor, Z. Radak, High altitude and oxidative stress, Respir. Physiol. Neurobiol., 158 (2007) 128-131.

12. M.F. Baird, S.M. Graham, J.S. Baker, G.F. Bickerstaff, Creatinekinase- and exerciserelated muscle damage implications for muscle performance and recovery, J. Nutr. Metab., 2012 (2012) 960363-960313.

13. D. Magrini, M. Khodaee, I. San-Millán, T. Hew-Butler, A.J. Provance, Serum creatine kinase elevations in ultramarathon runners at high altitude, Phys. Sportsmed., 45 (2017) 129-133.

14. J.M. Peake, S.J. Tan, J.F. Markworth, J.A. Broadbent, T.L. Skinner, D. Cameron-Smith, Metabolic and hormonal responses to isoenergetic high-intensity interval exercise and continuous moderate-intensity exercise, Am. J. Physiol. Endocrinol. Metab., 307 (2014) 539-552.

15. M.P. Schippers, O. Ramirez, M. Arana, P. Pinedo-Bernal, G.B. McClelland, Increase in carbohydrate utilization in highaltitude Andean mice, Curr. Biol., 22 (2012) 2350-2354.

16. G.D. Cartee, Mechanisms for greater insulin-stimulated glucose uptake in normal and insulin-resistant skeletal muscle after acute exercise, Am. J. Physiol. Endocrinol. Metab., 309 (2015) 949-959.

17. O.P. Adams, The impact of brief high-intensity exercise on blood glucose levels, Diabetes Metab. Syndr. Obes., 6 ( 2013) $113-122$.

18. N.E. Hill, K. Deighton, J. Matu, S. Misra, N.S. Oliver, C. Newman, A. Mellor, J. O'Hara, D. Woods, Continuous glucose monitoring at high altitude-effects on glucose homeostasis, Med Sci Sports Exerc., 50 ( 2018) 1679-1686.

19. O.O. Woolcott, M. Ader, R.N. Bergman, Glucose homeostasis during short-term and prolonged exposure to high altitudes, Endoc. Rev., 36 (2015) 149-173.

20. S.L. Wing, E.W Askew, M.J. Luetkemeier, D.T. Ryujin, G.H. Kamimori , C.K. Grissom, Lack of effect of Rhodiola or oxygenated water supplementation on hypoxemia and oxidative stress, Wild Envir. Med., 14 (2003) 9-16.

21. N.A. Guzel, H. Sayan, D. Erbas, Effect of moderate altitude on exhaled nitric oxide, erythrocytes lipid peroxidation and superoxide dismutase levels, Jpn. J. Physiol., 50 (2000) 187190.

22. Wozniak, G. Drewa, G. Chesy, A. Rakowsi, M. Rozwodowska, D. Olzewska, Effect of altitude training on the peroxidation and antioxidant enzymes in sportsment, Med. Sci. Sports Exerc., 33 (2001) 1109-1113.

23. M.C. Schmidt, E.W. Askew, D.E. Roberts, R.L. Prior, W.Y. Ensign, R.E. Hesslink, Oxidative stress in humans training to a cold, moderate altitude environment and their response to pytochemical antioxidant supplement, Wild Environ Med.,13 (2002) 94-105.

24. G. Gonzalez, G. Celedon, M. Escobar, C. Sotomayor, V. Ferre, D. Benitez, C. Behn, Red cellmembrane lipid changes at $3500 \mathrm{~m}$ and on return to sea level, High Alt. Med. Biol., 6 (2005) 320-326. 
25. J.F. Turrens, Mitochondrial formation of reactive oxygen species, J. Physiol., 552 (2003) 335-344.

26. R.A. Papandreou,L. Cairns, A.L. Fontana, N.C. Lim, HIF-1 mediates adaptation to hypoxia by actively downregulating mitochondrial oxygen consumption, Cell Metab., 3 (2006) 187-97.
27. P. Møller, L. Risom, C. Lundby, L. Mikkelsen, S. Loft, Hypoxia and oxidation levels of DNA and lipids in humans and animal experimental models, IUBMB Life., 60 (2008) 707-23. 